\title{
From International Horror Films to the Local Filem Seram: Examining the Cinematic Identity and Roles of the Malaysian Pontianak
}

\author{
"LEE YUEN BENG \\ SARATA BALAYA \\ School of Communication, Universiti Sains Malaysia, \\ 11800 USM Pulau Pinang, Malaysia \\ *Corresponding author: adrianlee@usm.my
}

Published online: 30 December 2016

To cite this article: Lee Yuen Beng and Sarata Balaya. 2016. From international horror films to the local filem seram: Examining the cinematic identity and roles of the Malaysian Pontianak. KEMANUSIAAN the Asian Journal of Humanities 23(Supp. 2): 161-174, https://doi.org/ 10.21315/kajh2016.23.s2.9

To link to this article: https://doi.org/10.21315/kajh2016.23.s2.9

\begin{abstract}
Malaysian horror films describe the pontianak as a supernatural entity with overflowing hair, vampire-like traits and a beautiful woman capable of seducing, charming and alluring her male victims. Once she has her target trapped, she transforms back into an unsightly pontianak and exacts her vengeance. Her capability of resurrecting from the afterlife and using her sexuality in seeking for death and destruction to those who have wronged her could position her as a villain or antagonist due to the chaos, destruction and murder to those regardless of innocence. Short of being labelled as a vamp or femme fatale, the pontianak continues being stereotyped as oppressive and monstrous for she gains supernatural strength and destablises a film's equilibrium. In short, the pontianak is seen as a threat towards partriachal order and such forms of representations are similarly shared in horror films globally. Using the films Sumpah Pontianak (1958) and Pontianak Harum Sundal Malam (2004), this paper examines the representation, identity and roles of the Malaysian cinematic pontianak within the contexts of local and global horror cinemas.
\end{abstract}

Keywords: Malaysian horror cinema, pontianak, patriarchy, villains, stereotype, internationalisation 


\section{Introduction}

The Malaysian pontianak has throughout the years become the most feared and recognised supernatural being in Malay folklore. With its roots deeply embedded within the Nusantara region, the legacy of the pontianak transcends time and space as for centuries, sightings of this mythical creature shared orally and in writing similarly tell of a woman dressed in white with vampiric qualities in Malaysia, Singapore and Indonesia. Although geographically separated, eyewitness accounts of the pontianak from these countries state how the pontianak is female, shrieks in a high-pitched tone, has long flowing hair and fangs, possesses ghost-like traits, and can only be subdued by striking a nail to the back of her neck.

Although the pontianak should theoretically be termed as the langsuyar, local societal folklores and popular culture often refers to this female vampire as the pontianak. The pontianak should also not be mistaken for Pontianak, which is located at the province of West Kalimantan, Indonesia. The belief in the existence of the pontianak stretches transnationally and regionally throughout Southeast Asian countries as it is known as the kuntilanak in Indonesia and pontianak in Singapore and Malaysia (Lee and Mahyuddin 2015). As such, the belief in the pontianak as a fearsome female with vampiric-like qualities is one that transcends borders and is similar with the global representation of female monstrosity in horror films.

The fear of the pontianak also transcends dimensions as her presence now roams the cinematic screens. Malaysian horror films in fact begun with the series of pontianak films in the 1950s, which were made by global and transnational forces and influences, for early Malaysian cinema was an amalgamation of Indian creativity and directors, Malay talents and acting, and Chinese capital and manpower (Lee 2012). Although Malaysian horror films adopted the concept of the global vampire with Western origins, the story of the pontianak remains heavily grounded within the contexts of local beliefs, mythologies, legends and fears. As such, films such as Pontianak (1957), Pontianak Kembali (1963), Pontianak Harum Sundal Malam (2004) and Paku Pontianak (2013) have continuously exploited local fears of the pontianak.

Pontianak films also share similar traits of hybridisation with J-horror (Japanese horror), which is known for hybridising the Western vampire with the classical Japanese theatre, kabuki (Lee 2012; Scherer 2016, 69) with Ringu (1998) being the most significant. Another similar trait shared by pontianak films and Asian horror is the usage of Noh and Kabuki-influenced shunen (revenge) and kaidan ghost mystery stories that employ localised versions of beliefs, religious 
practices, customs, values and traditions within the film plots (Lee 2012). Most prominent is the return of a murdered woman in the form of undead to execute revenge or justice upon her transgressors. These examples of vengeance and delayed justice are also found in the horror films of Korea, Japan and Thailand. Pontianak Harum Sundal Malam (2004) for example tells a tale vengeance committed by an undead woman. This is similar with Thailand's Nang Nak (1999) as the women in both films were murdered and returned as restless spirits or the undead seeking justice. As such, pontianak films although employing local beliefs and mythologies within its cinematic aesthetics and narratives, shares common stylistic and thematic conventions with horror films worldwide.

In order to appeal to the local audience through cultural verisimilitude and achieve a sense of proximity and familiarity, the mise-en-scène in pontianak films needs to be well-organised to be visually impactful. As such, throughout the years, the cinematic pontianak herself continues undergoing various forms of onscreen transformations in order to keep up with the changes in time, beliefs and technology. The mise-en-scène in pontianak films thus need to be constructed carefully to create a convincing social milieu and reality that suggests that however extreme the events are, they can always be understood as having direct social and economic causes. The settings, costumes, and lighting techniques in the composition of shots needs to establish a certain time and place; to introduce ideas, themes, and moods that enable a sense of identification with the audience.

Such forms of transformation can be seen through her costume and make-up, cinematography techniques, and sound and music, which continuously attempt to keep up with the advancement of technology while attempting to satisfy the wants and demands of an increasingly cinematic savvy audience. Computer generated imagery (CGI) is also increasingly used to generate special effects. The "modern day" pontianak in Pontianak Harum Sundal Malam is very much constructed carefully according to costumes that reflect the time in which the film was set, which is 1940s Malaya. The pontianak, Meriam, dons a simple long flowing robe and her face is painted white. The portrayal of the pontianak in Pontianak Harum Sundal Malam differs from the pontianaks of the 1950s and 1960s as Meriam has supernatural powers that enable her to fly and climb trees; she does not wear a rubber mask, neither does she have fangs (Lee 2012; Lee and Mahyuddin 2015).

Since the arrival of Islamic revivalism after the Iranian revolution of the 1970s, Malaysian horror films have often had scenes deemed as "unIslamic" removed or modified. Despite existing as one of the most feared characters in cinema, the role of the pontianak remains unclear as to whether she exists as the protagonist or antagonist within the Islamic view. This is because her return to avenge an 
unjust deed is carried out through murderous rampages as she seeks for those who had murdered her. In other films, she also returns for her lost child left behind during childbirth. This causes her presence in cinema to be ambiguous due to her presence as the living dead and as a female with vampiric like qualities. In addition, her ambiguity presents another form of difficulty because her existence as the un-dead is in defiance of Islamic beliefs of life after death. This notion of the pontianak living as the un-dead goes against the timeframe between death and akhirat, otherwise known as Barzakh, which transgresses the belief that the soul awaits judgement. For it is during Barzakh, or the time when the soul leaves the body and hovers above the body in the grave and is in a state of repentance while waiting to be resurrected on akhirat. This therefore leaves the presence of the cinematic pontianak on an ambiguous level on two levels (Lee 2012; Lee and Mahyuddin 2015).

The pontianak thus finds her cinematic presence continuously subjugated by changes in local cinematic regulations and guidelines as censors continuously attempt to define what is deemed as "scary" and "horrifying". For example, a disclaimer is required to be placed at the beginning of pontianak and Malaysian made horror films to remind viewers that the film is fictional and that the pontianak is merely a figment of one's imagination. ${ }^{1}$ It was also verbally agreed that scenes of ghosts emerging from graves and too much blood would not be shown, and that the pontianak could only appear in dream-like sequences. Furthermore, Malaysian filmmakers are prohibited from creating monsters that are too frightening as the monster can only appear in a dreamlike sequence and there must not be too much blood (Lee 2012, 199). As such, pontianak and horror films are required and contain "strong moral values" as public debates have taken place regarding the social and cultural effects of horror films on the Malay community and on their aqeedah (basic tenets of the Islamic faith). While horror filmmakers insist that contemporary horror films comply with cinematic regulations, political parties and figures such as UMNO, PAS, and Mahathir Mohammad have used the media in their attempt to reflect, negotiate, and revise the social and cultural perspective of horror films. This media panic has created a dichotomy of "The Islamists versus the Horror Films" as such public debates have focused on the effects of horror films upon the young and has been morally and religiously polarised (Lee 2012, 186).

Despite the pontianak having to undergo changes in line with the various cultural, religious, economic and political demands, one thing that remains consistent throughout the many pontianak films produced is the stereotypical representation of women. While the cinematic pontianak does not concur with how women in Malaysian cinema are stereotyped as two-dimensional, passive, or angelic, the pontianak however becomes the "evil woman" who makes an appearance in Malaysian horror. The horror genre, which globally sets itself apart 
from the other genres through its high cinematic output, successful box-office returns, and broad thematic appeal, often exploits the female character as monstrous and evil. In short, the Malaysian horror film or filem seram, often only uses a female monster/supernatural entity while male characters are almost never the monster/supernatural entity.

While this female monster/supernatural entity is locally seen as a "rebel" who goes against the system by disobeying the patriarchal structure, she is portrayed as monstrous and evil and would use anything within her means to achieve her goals. Such depictions of the woman as "evil" does not run far from Western depictions of female characters as the "monstrous feminine", for they are often portrayed for erotic purposes for characters in the story as well as its audiences (Mulvey 1975). Examples of female monsters/characters capable of upsetting the patriarchal narrative of a film plot can be found in Hollywood films such as The Vampire Lovers (1970), The Hunger (1983), The Exorcism of Emily Rose (2005) and Annabelle (2014). Although such female monsters are depicted as "strong and independent" and capable of upsetting the equilibrium of a film, ultimately she is killed or subdued by a man for her emancipation is often seen as taboo in society as she is seen as the source of male problems and the threat she brings presents a problem in society.

Such form of subjugation of female empowerment adopted by horror films around the world is also present in pontianak films. The misinterpretation of a pontianak or female monster as a strong female character becomes trickier in a Malaysian society where patriarchy is heavily imposed and where women must not be seen as more powerful than their male counterparts. And despite the change in times and roles that women play in today's society, women's representation in Malaysian horror films remain stereotyped and unchanged. What is most notable is the increase in horror films since the year 2000, whereby the number of such films portraying women as an evil character has increased. The most notable monster, and for that matter, female monster is the pontianak, as more than ten films featuring the pontianak have been produced.

As the majority of Malaysian made horror films tend to objectify women as abject, women are connoted as oppressed and the weaker gender. In addition, the portrayal of women in a negative manner also tends to stereotype them as evil beings capable of destabilising the normalcy of society. As such, it is important to examine the representation of women in pontianak films within the historical context of Malaysian cinema, which was built alongside the construction of the patriarchy ideology. 


\section{A History of Pontianak Films in Malaysia}

The first Malaysian pontianak film was directed by B. N. Rao. Titled Pontianak (1957) and released by Cathay-Keris, pontianak films proved to be a winning formula with a total of five films released. ${ }^{2}$ The release of Pontianak was timely for it coincided with the Eid al-Fitr celebrations (The Straits Times 1957, 4) and appealed to the Indian and Chinese communities (Barnard 2011). This could be because the film was released in Malay and dubbed in Cantonese for Hong Kong audiences (Barnard 2011). The film was screened in major cinemas for almost two months, an unusual occurrence for a Malay film at the time (Barnard 2011). The film's success led to two sequels, Dendam Pontianak (1957) and Sumpah Pontianak (1958) (Lee 2012). Using the genre formula of repetition and familiarity, Cathay-Keris continued to employ B. N. Rao and Maria Menado for Pontianak Kembali (1963) and Pontianak Gua Musang (1964).

The success of pontianak films then led to spin-offs and imitations by the Shaw Brothers' Malay Film Productions (MFP) through Ramon Estella's Anak Pontianak (1958). The film displayed technical superiority to Cathay-Keris' films through better camera movements (virtuoso tracking shots), lighting techniques (neo-Expressionist use of shadows), and visual effects (pseudo-Gothic lettering for the opening credits), and were comparable to the horror films of James Whale. MFP however only produced two pontianak films, the other being Pusaka Pontianak (1964) (Lee 2012). In 1975, the eighth and final pontianak film, titled Pontianak was released before the beginning of the 30 year hiatus in the production of pontianak films. Locally made horror films had then lost their lustre with Malaysian audiences and the horror genre became almost nonexistent. It must, however, be noted that although no pontianak films were produced during these 30 years, horror films were produced on a smaller scale but failed to capture the imagination of audiences (Lee 2012). ${ }^{3}$

The release of Pontianak Harum Sundal Malam in 2004 marked the end of the 30 -year hiatus. The film which achieved critical and commercial success (re)popularised the horror genre by exploiting the infamous pontianak myth which has deep mythical roots in Asia (Lee 2012). The film became a commercial success as it screened at 29 cinemas, made a return of RM 3.2 million (USD 0.8 million), received accolades in Malaysia and abroad (Best Editing and Best Male Supporting Actor at the Festival Filem Malaysia 17 [17th Malaysian Film Festival], Best Film Production, Best Cinematography and Best Editing at the 2004 Malaysian Film Workers Association [PPFM] Oscars), and became the first Malaysian horror film in the post-2000 era to be commercially screened at overseas festivals (Spain, London, Bangkok, and Singapore) and win foreign awards (Best Director, Best Cinematography, and Best Music at the Estepona Horror and Fantasy Film Festival [Spain, 2004], Best Actress at the 
Asia Pacific Film Festival [Japan, 2004]) (Lee 2012). Eventually, Malaysian cinema continued producing films featuring the pontianak and from 2004-2013, with a total of six films such as Pontianak Menjerit (2005), Tolong! Awek Aku Pontianak (2011), and Paku Pontianak (2013) produced (Lee and Mahyuddin 2015).

\section{Reading the Pontianak: Understanding identity, sexuality and psychoanalysis}

The employment of female monstrosity, however, does not only articulate male fears around female empowerment. Rather, the usage of female monstrosity poses a broader challenge to a sense of normality, and cultural and religious beliefs in particular. The anxieties over the construction of gender can be studied using psychoanalysis as Mulvey's (1975) notion of male gaze, identity and female as fictitious entity, gives way to the resurgence of the feminist movement in late 1960s; as a key way to understanding the pleasures of cinema and gender representation informed by Freud and Lacanian psychoanalysis. Freudian and Lacanian psychoanalysis demonstrates the female for male's representation of lack, regarding them as objects within the fantasies of male desire and sexuality. Mulvey concluded that the pleasures of cinema is offered only to a masculine spectator by giving an underprivileged identity to female subjectivity, further differentiate and identify the men as the active "bearer of the look" and "women as image" to be looked at and fetishized as the object of male heterosexual desire (Mulvey 1975, 9). Attained from this model, cinema offers a number of possible pleasures, mainly "voyeuristic pleasure" as "he can look without being looked back" at (Stacey 1994, 21), where sexual differences are rejected through the darkness moment of cinema. The feeling of castration through voyeuristic approaches done cinematically on women's bodies is intensely fetishized, framing the male as physically and symbolically dominant in society. The primary proposition of psychoanalysis and visual pleasure locates the woman as a sexual object, submissive to the male's sexual stimulation and a form of security that enhances the "patriarchal kinship systems, which maintain the binary oppositions based on the sex/gender dichotomy" (Yilmaz 2012, 4). Voyeuristic pleasures allow the male viewer to have some kind of authority over the woman on screen. It enables them to disavow the threat of castration formed within the moment of darkness by rejecting the sexual and gender identity (Mulvey 1975, 22) that the woman signifies.

The pontianak, a Malaysian vampire that exists in mythologies, carry a different interpretation which goes against this global understanding as women as sexual objects, for the fearsome and heroic features of the pontianak contest patriarchy's narrative of gender and sexuality. The cinematic representations of the pontianak over time have blurred the boundaries between traditional belief and popular 
culture (Lee and Mahyuddin 2015) as judgmental identification to what constitutes binary oppositions based on gender identities and role dichotomy that causes the role of the women in pontianak films becomes ambiguous and misleading. Developing through Lacan's theory of "the mirror phase", Mulvey locates the unconscious origins of pleasure in identification (Mulvey 1975, 10) that leads her to define female identity in moments of erotic contemplation and further enhances the feminine perspectives into passive qualities. Here, it does not justify the representation of monstrous feminine characters like the pontianak into passive perspectives; given the fact she stretches transnationally throughout Southeast Asian countries and becomes the most recognised woman monster in the cinemas of Malaysian, Singapore and Indonesia (Lee and Mahyuddin 2015).

Thus, the pontianak as monstrous feminine does not exists as an object of desire and repulsion as her existences as the "female monstrosity" (Creed 1993) refers to a dangerous woman. Creed states that there are seven potential faces of female monstrosity, the archaic mother, monstrous womb, vampire, witch, possessed monster, the castrator or the female castatrice and castrating mother. Murlanch (1996) takes this argument further by stating how the woman represents the most extreme threat towards male identity, as the woman is the paradigm of feminine beauty and the incarnation of the female castrator. Such women are therefore identified as seductive, dangerous and a threat that brings bad consequences to men (Doane 1991, 3). The threat of castration is rooted in the Oedipus complex, for according to Freud, the woman terrified because she herself is a castrated human being and women are primarily terrifying because they might castrate (Creed 1993). Creed argues that the different representations of the monstrous feminine is a result of male unease with women's sexuality and power relations within their reproductive capacities. The monstrous feminine thus cannot be examined only by seeing her as a masculine monster, because the "reasons why she terrifies her audience are quite different from the reasons why the male monster horrifies his audience" (Creed 1993).

A typical representation of woman as sexual stereotypes, which is recognised around the world is now challenged by the pontianak through the monstrosity's sexual approach (Creed 1993). Despite this, the pontianak is portrayed as beautiful woman capable of seducing her male target, and is capable of transforming back into the pontianak. The pontianak's capabilities within desire and repulsion as Creed describes, has destabilised the equilibrium of the film's plot and is seen as going against the patriarchal order of gender identity and sexuality. For Lacan, the early stages of identity formation can be explained as the moment a child finds his/her image in the mirror (or mother), creating the sense of completeness for the lack through a stage of misrecognition (Lacan 1977, 7). The illusion is narcissistically fantasized, and concludes the psychoanalysis that recognition is overlaid with misrecognition (Lacan 1977, 7) 
in which the sense of identity and recognition situates the agency of the ego as the child grows up (Stacey 1994, 22).

Locating the pontianak within the mirror phase provides her the space to rise from the dead, create a sense of completeness through her ideal image of monstrosity, and when the ideal ego ascends, she desires to carry out revenge using her sexuality. The pontianak is untouchable and has gendered features strong enough to transcend gender boundaries. The pontianak, located within an active female-centric narrative demonstrates the competence of a female to become the point of view of a camera. This act disables the male gaze alongside gender and sexual differences on screen and the way a woman should be looked at in society as whole. However, these images do not last on screen (or in the mirror) as the pontianak's supernatural powers is limited by the imaginary boundary that includes the imaginary construction of patriarchal ideology and heteronormative positions (Creed 1989, 132). Here, she will be punished, banished or vanished for she has transgressed against the law of nature, usually in support of male-biased agendas, which fit into the dichotomy structure of society. Using this as groundwork, this paper examines if the identities and roles of the pontianak of two different eras represent a form of female empowerment in Malaysian cinema through the films Sumpah Pontianak (1958) and Pontianak Harum Sundal Malam (2004).

\section{The Cinematic Identity and Roles of the Pontianak}

B. N. Rao's Sumpah Pontianak (1958) begins with Chomel (played by Maria Menando) sobbing over her father's grave. She seems to be pleading for forgiveness, and asking her father to release her from her suffering, as she is a hunchback with an ugly face. Her father's ghostly voice answers in disappointment, reminding her that if she would have listened to his advice, none of this would have happened. This scene describes how Chomel only desired to be happy and beautiful but her appalling looks, crying and guilty conscience makes her seem weak and submissive. Throughout the film, she protects her daughter Maria and means no harm to the villagers as she regrets her wrongdoing. She laments her ill fate of being cursed to have the blood of a pontianak and having a nail hammered into her neck by the villagers renders her powerless. The powerless pontianak then wanders to a distant village where no one recognises as she goes searches for food and work. The villagers unsympathetically turn the ugly hunchback away as her ugliness is seen as a transgression against nature and society's concept of beauty. Chomel becomes a figure of suffering who expects to be beaten down due to her appearance until an old man offers help. 
The film continues with unwanted events taking place in the village and all fingers point to Chomel. This makes it more difficult for Chomel to convince them that she means no harm. The film continues with Maria having visions of her mother and wanders into the forest hoping to find her mother but is kidnapped. Chomel realises her daughter is in danger and as she rushes to save Maria, she stumbles into Ali and his friends who are also looking for Maria. Chomel begs them to remove the nail from her neck so that she can use her supernatural powers to rescue her daughter. The film ends with Chomel being transformed into a beautiful mother and reunited with Maria. She advises her daughter not to look for her and return to her husband as they cannot be together for Chomel does not belong to the human world. The final dialogue, "nasib baik pontianak datang menolong" (Luckily the pontianak came to help) shows how Chomel has attained some forms of compensation for her wrongdoings and hardship as she is seen as a hero. Chomel is therefore not the villain, but an antihero who uses her powers to defeat all evildoers, protect her daughter and villagers indirectly.

In Pontianak Harum Sundal Malam, the pontianak has the ability to dramatise her pain. This enables her to contest notions of gender, identity and sexuality in a more impactful manner. Directed by Shuhaimi Baba, the film takes place in the late 1940s in the small town of Kampung Paku Laris, Kelantan. The film begins with a woman massaging Marsani as he reads to his friend, Danial a story of a pontianak exacting revenge over her death. The camera keeps them all within eye-level but uses close-ups on the woman's feet massaging Marsani. The film's narrative is constructed around Meriam, the pontianak, who led a peaceful life with her husband before being murdered by Marsani. Meriam, a beautiful gamelan dancer attracts many men in her village including the wealthy and influential Marsani. She however rejects his advances and during a struggle, Marsani and his henchmen kill a heavily pregnant Meriam.

They run off with her valuable dance accessories and precious gamelan gong. The film continues with series of unfortunate events as Meriam who returns from the dead seeks for vengeance over her death. Fast-forward to the present time and to Maria, who bears identical looks with Meriam. Maria who works for Anna, Marsani's daughter-in-law, is also a traditional dancer who unconsciously revives the spirit of Meriam during a dance. The revisiting of the spirit indicates that Meriam, who is transformed into a pontianak has completely taken control over Maria's body in order for her to exact her vengeance upon Marsani. Under Meriam's possession, she attempts to seduce Norman, Marsani's grandson, to disrupt the peace in Marsani's family. During the final confrontation, order is restored as Marsani apologises for his wrongdoing before Meriam and dies. While it could be assumed that the pontianak is simply seeking for an apology, however, what is achieved through Marsani's apology is the disruption of 
patriarchy as he kneels before her. Meriam's character and actions creates more complex representations of both women and men as she stretches the boundaries of traditional portrayal of women.

On the contrary, Meriam's character remains ambivalent to what she actually signifies: beautiful, seducing and unpleasant at the same time. In one scene, Anna stops her car to offer Meriam a lift and when she does not respond, Anna continues driving. An intense close-up of Anna's staring eyes is framed and reflected in the mirror using her car's rear-view mirror, which reverses the gaze definition, cinematic pleasure and feminine qualities in which Mulvey locates the female identity within the male's sexual contemplation. The establishment of the pontianak between subjective and objective images in terms of identification both visually and cinematically causes the pontianak to become the subject, "using her body as the abject that has capacity of producing different identity" (Kristeva 1982, 4). It is her undifferentiated identity that threatens patriarchal orders through meanings and identities between the real and reel imaginary axis. However, the pontianak's character remains stereotyped as in line with the conventional endings of horror films for she needs to be punished, banished or vanished in order for stability to be restored and as "an expression of relief" (Creed 1993, 14) from establishing a permanent gender powers in society.

\section{Pontianak: Localising Religion, Women and Patriarchy}

The re-emergence of pontianak films should not necessarily be regarded as a positive development as the return of an undead capable of creating more democratic space would be just a false claim as pontianak films operate within larger aspects of a dominant ideological and economic system. The pontianak being a folklore creature, creates a strong sense of a religious, gender and cultural struggle between different classes depicted visually and cinematically. In contemporary pontianak films, the ending would favour the rich and male, while subtly creating more space for debate on gender, identity and sexuality. The greatest concern involves the patriarchal system that provides a false ideological consciousness that men are superior to women and how men are strong and active, while women are weak and passive. While pontianak films often end with the pontianak dying, vanishing or being banished due to censorship restrictions, the pontianak throughout the film uses her supernatural power to disrupt the disequilibrium of patriarchy order by breaking generic conventions. This disruption however does not mean an articulation of fear about the empowerment of women (Lee 2012), as the "root cause behind the oppression in Malaysia lies with patriarchy and how Islam has been continuously used as a tool of control by men to maintain power over women" (Yap 2016). 
In Malaysia, Malay girls are expected to be feminine with Islamic female values through their clothing and daily duties (Ong 1990, 261). The honour and shame of a family is placed upon women and not men, and this constrains the Malay/Muslim woman's spatial movement and social interaction until new opportunities such as fair employment and education background is given to both genders. This stereotyped image of the traditional woman has formed the gender system in the Malay community as the sexuality and identity of a Malay woman is restricted. In traditional Malay literary works, Malay women are depicted as weak and willing to sacrifice their happiness for the well being of others (Krueger 1984). It is this view that reinforces patriarchy power and continuous oppression of Malay/Muslim women although Islam never sets different rights for men and women for the Quran never differentiates between men and women (Yap 2016). This societal belief that men are more superior to women is embedded within cultural practices and beliefs and in Malaysian cinema.

In Malaysian cinema, a Malay/Muslim woman who simply drapes a headscarf/tudung over her head or sarong around the body (particularly if the sarong is tucked under the armpits) is seen as "unIslamic". The cinematic representation of the pontianak as the central figure of a narrative breaks away from the stereotyped weak and submissive portrayal of women in Malaysian cinema. The pontianak who is empowered with supernatural powers not only capably returns from the dead but is also capable of exacting vengeance upon her stronger male characters. Her capability of transcending time, dimensions and space to return from the dead, whilst transgresses Islamic beliefs, demonstrates a form of gender empowerment for a reversal of roles occurs. The pontianak then as a woman, takes over the role of the strong and active character, one which has often been reserved for leading male characters. Her victims, which are often male, often appear to be weak and submissive as they are either murdered or have their lives destroyed by the pontianak. Her powerful shrieks, capability to fly and being dressed in a long white robe while gazing at her male victims disrupts the narratives of cinema, which have been traditionally male-centric and male dominant. As the stronger character, the pontianak negotiates religion, culture and gender within a male dominant industry and narrative. Yet, because society remains patriarchal, the threat from this monstrous feminine needs to be destroyed in order for a sense of normalcy to be restored. Thus, the common ending in pontianak films sees her either punished, banished or vanished for she continues to be subjected to patriarchal domination where all power remains in the hands of men in a male dominant industry and society. As such, no matter how many pontianak films are produced, the ending would still remain in favour of patriarchy. Despite being wronged and in seek for justice, the pontianak remains marginalized for her interests and desires are labelled as transgressions. 


\section{Conclusion}

In summary, pontianak films are about a female character who drives the plot forward but does not belong to human society as she is destructive towards men (Scherer 2016, 63). Such forms of on-screen representation of the female undead and female monstrosity are globally shared as she is capable of disrupting male dominant narratives and causing disequilibrium. The portrayals of Chomel and Meriam and Malaysian pontianak films contest the taken-for-granted system or assumptions concerning gender, identity and sexuality in our society by placing women identities as central in film and society. While Chomel and Meriam return from the undead for revenge and closure, Chomel gains sympathy and trust through her suffering but Meriam loses her own sense of humanity without losing the audience's sympathy. As pontianak films place women as central figures while side-lining the males, this allows the pontianak, like the female spirits, monsters and undead of Asian and Western horror films to renegotiate and realign religious, gender, sexual and cultural politics. On the other hand, the need to restore stability and equilibrium in the ending (the restoration of patriarchy) of pontianak films does not justify the pontianak's power and identity. This is because the representations and supernatural powers of Chomel, Meriam and other pontianak films means an eventual failure to overcome the usual weak and submissive portrayal of women in both local and international horror cinema for they remained subjugated to patriarchal forces.

\section{Acknowledgement}

The authors wish to acknowledge that this paper was made possible with the funding from the Universiti Sains Malaysia Short Term Grant.

\section{Notes}

1. Introduced in 1996, films released in Malaysian cinemas were rated according to six categories: U; PG-13; 18SG; 18SX; 18PA; and 18PL. Under the new censorship guidelines released in 2010, these ratings have been revised to $U$ (Suitable for general viewing); PG-13 (Children under 13 not to be admitted unless with parental guidance); and 18 (For adults aged 18 and above for film may contain mild violence, horror, sex scenes, nudity, sexual dialogues/references, religious, social or political aspects.

2. There no longer exists any remaining copy of the film.

3. In the $1980 \mathrm{~s}$, a series of such horror films or films containing supernatural elements such as Perjanjian Syaitan (1981), Toyol (1981), Anita Dunia Ajaib (1981), Setinggan (1982), Perawan Malam (1982), Ilmu Saka (1984), Mangsa (1985), Rahsia (1987) were commercially unsuccessful and depicted supernatural and spiritual beings such as toyol, hantu (ghost), and syaitan (Satan). In the 1990s, the only (possible) horror films are Main-Main Hantu (1990) and Fantasi (1993). 
Fantasi, however, was initially banned for depicting supernatural creatures, which contradicts Islam. In 1993, Fantasi was finally released after the intervention of Mahathir Mohammad, the film title changed from Fantasia to Fantasi and the unIslamic scenes removed (Lee 2012).

\section{Bibliography}

Barnard, T. P. 2011. Films of change in early Singaporean film history. In Singapore independent film, ed. Michalik, Y., 47-48. Marburg, Germany: Schuren.

Creed, B. 1993. The monstrous feminine: Film, feminism and psychoanalysis. New York: Routledge.

Creed, B. 1989. Untitled entry. Camera Obscura 20(21): 132-137.

Doane, M. A. 1991. Femmes fatales: Feminism, film theory, psychoanalysis. New York: Routledge.

Kristeva, J. 1982. Powers of horror: An essay of abjection. New York: Columbia University Press.

Krueger, D. 1984. Success and the fear of success in women. London: Collier Macmillan.

Lacan, J.1977. The mirror stage as formative of the I as revealed in psychoanalytical experience. In Ecrits: A selection, trans. Sheridan, A., 1-7. New York: Norton.

Lee, Y. B. 2012. The Malaysian digital indies: New forms, aesthetics and genres in post2000 Malaysian cinema. PhD diss., University of Melbourne, Australia.

Lee, Y. B. and Mahyuddin Ahmad. 2015. The digital villain. Mapping cross-cultural fears of the Pontianak in Malaysian, Singaporean and Indonesian cinemas. Paper presented at the Indonesia International Communication Conference, 10-11 December, Universitas Indonesia, Jakarta.

Mahyuddin Ahmad. 2004. Islam, Pontianak and the supernatural in film. Popular film at the crossroads in Malaysia. Chulalongkorn University: Journal of Communication Arts 25(4): 26-36.

Mulvey, L. 1975. Visual pleasure and narrative cinema. Screen 16(3): 6-18, https://doi.org/10.1093/screen/16.3.6.

Murlanch, I. F. What's in a name? Construction of female images in film "noir": The case of Fritz Lang's "The Blue Gardenia". Atlantis 18(1/2): 105-115.

Ong, A. 1990. State versus Islam: Malay families, women's bodies, and the body politic in Malaysia. Ethnologist 17 (2): 258-276, https://doi.org/10.1525/ae.1990.17.2. $02 \mathrm{a} 00040$.

Scherer, E. 2016. Well-travelled female avengers: The transcultural potential of Japanese ghosts. In Ghost movies in Southeast Asia and beyond: Narratives, cultural contexts, audiences, eds. Lauser, A. and Braunlein, P. J., 61-82. Leiden, South Holland: Brill Publication.

Stacey, J. 1994. Star gazing: Hollywood cinema and female spectatorship. London/New York: Routledge.

The Straits Times. 1957. Advertisement column 1, 1 May, 4.

Yap, T. G. 2016. Forum: Patriarchy, not religion fuelling oppression of Muslim women in Malaysia. Malay Mail, 11 April.

Yilmaz, N. 2012. Gender politics and feminism in Caryl Churchill's "Cloud Nine". MA diss., University of Barcelona, Spain. 